\title{
Fish-based food vendor's compliance with good processing practices in Bogor, Indonesia
}

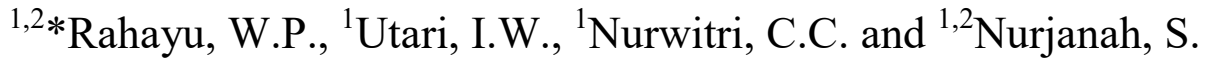 \\ ${ }^{1}$ Department of Food Science and Technology, IPB University (Bogor Agricultural University), Bogor \\ Indonesia \\ ${ }^{2}$ Southeast Asia Food and Agricultural Science and Technology (SEAFAST) Center, IPB University (Bogor \\ Agricultural University), Bogor Indonesia
}

\begin{abstract}
Article history:
Received: 19 March 2020 April 2020

Accepted: 23 April 2020

Available Online: 9 May 2020

Keywords:

Fish-based product

Compliance,

Good practices
\end{abstract}

Received in revised form: 21

\section{DOI:}

https://doi.org/10.26656/fr.2017.4(5).115

\begin{abstract}
Food for school children may become unsafe if its raw materials and handling processes are not well controlled. This study aimed to determine the level of compliance of the vendors with good processing practices. The method used was the development of vendor compliance criteria, observation of vendors' behavior, and exploration of the source of the problem. The results of the study on 100 types of fish-based food product which are sold by 63 vendors in 50 schools (elementary schools, junior high schools, senior high schools, and universities) indicated only $46 \%$ of vendors were compliant and there was still $26 \%$ of vendors who did not carry out the good food processing practices. The problems identified were no access to running water to wash hands and equipment $(100 \%)$, the absence of protective clothes for the workers (92\%), and the filthy conditions on the surface of the booth (81\%), the display (65\%), and the workers' hands (73\%). The results obtained also indicated that the compliance level of the vendors did not correspond with their educational background. From the results of this study, it is suggested that local health authorities should conduct a more targeted extension program for fish-based food for school children vendors.
\end{abstract}

\section{Introduction}

Food-borne diseases are reported to significantly increased every year. Each year as many as 600 million people in the world fall ill after consuming contaminated food and caused 420,000 people to die. More than 50\% of cases of diarrhea are also caused by contaminated food (World Health Organization [WHO], 2015). Fishbased foods are perishable and need to be handled very carefully. In the US, a total of 1,661 cases were caused by the consumption of fish and most of them were caused by scombroid or ciguatera intoxication (Centre for Science in the Public Interest [CSPI], 2001). In Jakarta, Indonesia, in 2016 there were 213 cases of food poisoning and $52.4 \%$ was caused by seafood and fishes (Mabruroh and Ciptaningtyas, 2017). This indicated a safety concern of fish-based foods and Bogor as Jakarta's satellite city likely shares a similar potential problem.

Fish-based foods are often found in a variety of foods for school children. Food for school children is ready-to-eat food that is sold at school yard can be consumed directly at the purchasing site. It can be classified into four categories, which are main meals, snacks, beverages, and fruits. Food for school children is one of the main concerns of the Indonesian government because it is widely consumed by Indonesian children. The report of Monitoring and Verification of Food for School Children Safety Profile in 2008 showed nearly $100 \%$ of school children have the habit of buying and consuming foods at school (National Agency of Drug and Food Control [NADFC], 2013). This fact showed that foods for school children were very interesting for them. The availability of foods for school children in public places allows them to eat more of those foods.

Food vendors have a role in implementing good processing practices to ensure that their products are safe to eat. They also have to control the cleanliness of their stalls and the surrounding environment to protect the foods from cross-contamination. However, the implementation of good processing practices by fishbased foods for school children vendors has not become a common matter of concern. The previous study 
conducted in Ghana showed that food vendors in educational institutions generally adhered to good food hygiene practices with regards to regular medical examinations $(93 \%)$, protection of food from flies and dust $(55 \%)$, proper serving of food $(100 \%)$, good hand hygiene $(63 \%)$, and the use of personal protective clothing (52\%) (Monneyl et al., 2013). Yet, another study that took place in Yogyakarta, Indonesia, showed that about $64 \%$ of food vendors in elementary school had limited knowledge of prohibited substances for food and about $40 \%$ of the vendors had limited knowledge about food hygiene and sanitation (Nasikhin et al., 2013). Therefore, it was considered important to do research that focused on fish-based foods for school children to know the vendors' compliance with good processing practices.

This study aimed to determine the level of compliance of the fish-based food vendors with good processing practices.

\section{Materials and methods}

This study was conducted in Bogor City in 50 schools, which comprised 21 elementary schools, 11 junior high schools, 13 senior high schools, and 5 universities. As many as 63 fish-based food vendors were observed in this study. The research process consisted of questionnaire arrangement; fish-based food vendor selection; questionnaire validation; interview and observation; data analysis; and level of compliance determination.

\subsection{Questionnaire arrangement}

The questionnaire was arranged with reference to the Book of Food Safety Counseling in Schools (Rahayu et al., 2005), the National Agency for Drug and Food Control (NADFC) regulation on procedures for inspection of food production facility in home-industry (NADFC, 2012a), and Bogor Agricultural University canteen inspection report (IPB, 2012). The first reference became the source of information regarding good readyto-eat food processing practices. The second reference provided required observation elements and standard of compliance of food producers. The gaps between the first and second references were analyzed and adjusted using the third reference. Then, the questionnaire was arranged based on the gathered information.

There were two main parts of the questionnaire, which were: 1) interview part (to gather information about the vendors' food processing practices) and 2) observation part (to determine the vendors' compliance to the good processing practices). The questionnaire was organized into distinctive sections which consisted of the vendor's educational background, selling location (which kind of educational institution), selling place (inside or outside the school), supporting selling facility, type of food sold, treatment of processed food and condition of storage, the interaction between water needs for processing and water sources, type of waste container, and an observation checklist to determine compliance level with good processing practices.

\subsection{Fish-based food vendor selection}

The number of respondents was determined by using the Slovin formula (Sarwono, 2006). It was done based on the assumption that there was one vendor in every school (elementary school, junior high school, and senior high school) and three vendors in each university. Then sampling was conducted randomly using the stratified sampling method, which is the type of sampling method which divides the population into stratum (Setiawan, 2005).

\subsection{Questionnaire validation}

The questionnaire was tested for clarity and validity on 10 randomly selected vendors. The pretest result was used to revise the initial questionnaire. The final version of the questionnaire was used to collect data from the respondents.

\subsection{Interview and observation}

The interview and observation were conducted during the school hours, i.e. at 08.00-16.00. The questionnaires were filled out by the surveyors.

\subsection{Data analysis}

The data obtained were analyzed using frequency calculation function (descriptive statistics) using IBM SPSS version 20 program. The frequencies and the percentages of responses to each question were computed with Microsoft Excel.

\subsection{Level of compliance determination}

Table 1. Food vendors compliance level standard

\begin{tabular}{cccc}
\hline \multirow{2}{*}{ Compliance Level } & \multicolumn{3}{c}{ Maximum number of deviations } \\
\cline { 2 - 4 } & MI & MA & CR \\
\hline Compliant & 2 & $1-2$ & $1-2$ \\
Partially compliant & 2 & 3 & $3-5$ \\
Non-compliant & 2 & $>3$ & $>5$ \\
\hline
\end{tabular}

Information: MI (minor), MA (major), CR (critical)

The food vendor's compliance level standard could be seen in Table 1. This standard was arranged based on food inspection system for the food industry (Rahayu et al., 2005; NADFC, 2012a). There were some modifications made to the standards, considering some gaps and differences between the food industry and the 
Table 2. The selected elements of interview and observation in the questionnaire

\begin{tabular}{|c|c|c|c|c|}
\hline & Selected Elements & \multicolumn{3}{|c|}{ Category } \\
\hline A & Storage & Minor & Major & Critical \\
\hline 1 & Raw materials and finished goods are stored separately & & & $\checkmark$ \\
\hline 2 & The place to store/display food is clean & \multicolumn{3}{|c|}{$\checkmark$} \\
\hline $\mathrm{B}$ & The hands of workers and equipment & Minor & Major & Critical \\
\hline 3 & Worker's clothes look clean & & & $\checkmark$ \\
\hline 4 & Workers wear protective clothing/aprons & $\checkmark$ & & \\
\hline 5 & Worker's nails look clean and neat & & & $\checkmark$ \\
\hline 6 & Worker's hands look clean & & & $\checkmark$ \\
\hline 7 & There are no injuries in the hands of workers & & & $\checkmark$ \\
\hline 8 & Workers do not use jewelry and watches when processing food & & & $\checkmark$ \\
\hline 9 & $\begin{array}{l}\text { The availability of running water that is used by workers to wash their hands and equipment } \\
\text { used by workers to wash their hands }\end{array}$ & & $\checkmark$ & \\
\hline 10 & The availability of running water/water supply facilities for washing equipment & & $\checkmark$ & \\
\hline 11 & Cookware and cutlery are clean & & & $\checkmark$ \\
\hline 12 & Worksurface cleaning tools and materials are available & $\checkmark$ & & \\
\hline $\mathrm{C}$ & Cooking & Minor & Major & Critical \\
\hline 13 & Cooking oil used is fresh & & & $\checkmark$ \\
\hline $\mathrm{D}$ & Selling location & Minor & Major & Critical \\
\hline 14 & The working surface of the shop is clean & & $\checkmark$ & \\
\hline 15 & The location around the shop is clean & & $\checkmark$ & \\
\hline 16 & All equipment is protected from rain splashes & & $\checkmark$ & \\
\hline $\mathrm{E}$ & Waste disposal & Minor & Major & Critical \\
\hline 17 & Trash and waste bins are available in the nearby location & & & $\checkmark$ \\
\hline 18 & No animals are roaming in the location & & & $\checkmark$ \\
\hline
\end{tabular}

vendors. The questions intended to evaluate the level of compliance were divided into three categories, which consisted of minor category ( 2 questions), major category (6 questions), and critical category (10 questions). The selected elements of interview and observation in the questionnaire as categorized as minor, major and critical are shown in Table 2. Each respondent's responses that did not conform with good processing practices were counted. Then, the level of compliance can be determined based on the sum and category of the deviations.

\section{Results and discussion}

\subsection{Characteristic of vendors}

Vendors who became the respondents in this study had different educational backgrounds. The results indicated that most of the vendors (37\%) were only had elementary school level education. However, not all vendors had a low level of education. Some vendors had studied at the diploma or undergraduate school $(6 \%)$ (Figure 1). Education is expected to provide insight or knowledge to humans, including knowledge about food safety. Food safety knowledge is an important aspect that shows the level of the vendors' understanding of food safety (Anggitasari et al., 2014). A person's knowledge of the importance of food safety greatly influence his attitudes and practices in selecting, processing, and storing food (Andarwulan et al., 2009). With more knowledge of food safety, it is expected that a person will have better attitudes and practices regarding the safety of food, and in terms of food vendors, it will encourage them to sell foods with good quality and nutrition (Anggitasari et al., 2014).

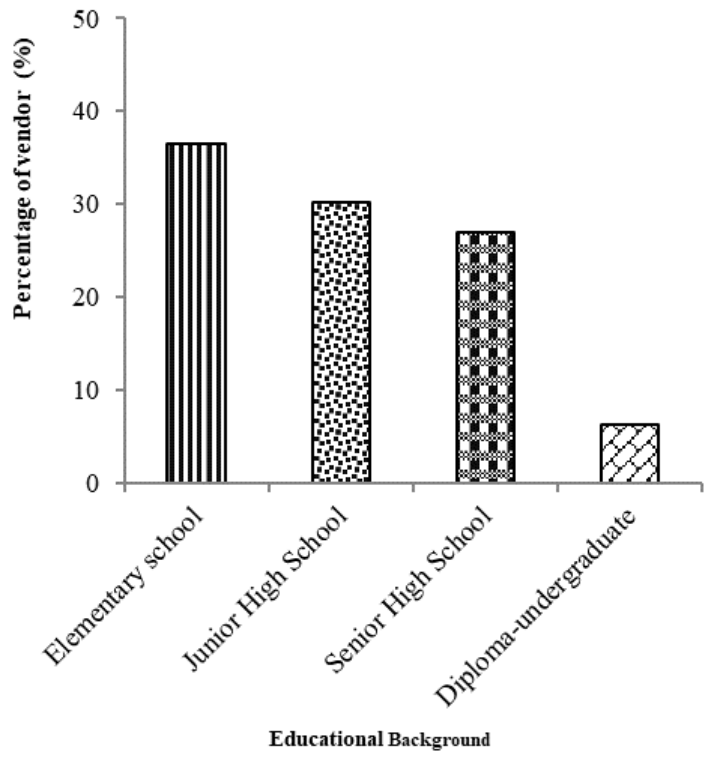

Figure 1. Vendor's educational background

Various kinds of food for school children are easily found in the school environment, whether in the form of snacks, main meals, beverages, or fruits. Fish-based 
foods for school children are generally made into snacks and main meals. The fish-based main meals commonly sold are siomay, batagor, pempek, takoyaki, okonomiyaki, boiled green shellfish, steamed fish, fried fish, and so on. The raw material used to make those foods was not limited to one type of fish, but a variety of fish, shrimp, crab, octopus, and green shellfish. Those raw materials can also be processed to make snacks for school children, such as otak-otak, fried meatballs, and processed seafood which were generally served like satay.

Food for school children vendors sold their products not only in the school canteen but also in the schoolyard or outside the schoolyard. Those who vend in the school canteen commonly use means such as display windows or permanent buildings and desks, whereas those who were outside and inside the schoolyard generally used a cart, handcart, or motor vehicles. This condition was because the vendors outside the canteen cannot be settled, which the vendors in the canteen can do, so they used movable vending facilities (Figure 2).

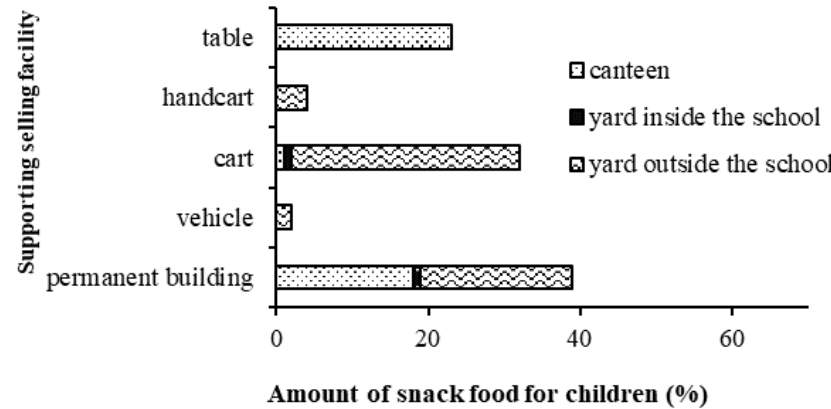

Figure 2. Interaction between supporting selling facility and selling place

The environmental condition of some vending site which was located at the roadside was crowded. The crowdedness was caused by parents who waited outside the school as well as the multitude of people and vehicles passing by. The road condition, which was quite narrow with only one car able to pass at a time, resulted in the distance between the vehicles with the displayed foods was very close (Yunita et al., 2016). This condition causes a lot of dust around the food which contains a lot of microbes and contaminants. This indicated that there was a higher risk of biological and physical hazards contamination of foods sold outside the schoolyard than those in the canteen. The non-indigenous bacteria especially Salmonella spp. can be easily found in the environment. Salmonellosis due to Salmonella spp. infection result in diverse clinical manifestations such as typhoid fever, caused by S. enterica serovar Typhi and self-limiting diarrhea caused by the non-typhoidal Salmonella serovars (De Jong, 2012).

\subsection{Processing condition}

From the results obtained, all the vendors prepared the fish-based food for school children by separating raw and cooked materials. Separation of raw and cooked material was done to keep the raw materials from contaminating cooked foods or products that were ready to eat. This showed a high awareness of food vendors toward safe food handling. It is nearly always possible to detect a range of human pathogenic bacteria on any fish or fish product that has not received any bactericidal treatment. Some of these pathogens may constitute part of the natural flora on the fish (pathogens from the aquatic environment) or be there as a result of unavoidable contamination (pathogens from the general environment). Yet, it is common for these pathogens that some growth in the fish products is required to produce disease in humans (Raini et al., 2004). The growth of pathogens in raw fish which intended to be cooked only gets a little safety concern. Only limited growth is possible before spoilage causing rejection and it is usually in borderline cases because cooking can destroy the pathogens. The growth of pathogens from animal or human reservoir gives no direct safety concern in raw fish which intended to be cooked before consumption as described above, but it may constitute a secondary hazard due to the increase of spread and contamination of the processing or kitchen environment with these pathogens (FAO, 2004).

The storing of food was performed differently by each vendor. Generally, the vendors had been prepared half-cooked food or processed food that was ready to be cooked on the vending site. Those foods were stored at first and then partially displayed. Mostly, the storage was done at room temperature, but some vendors stored the foods in the refrigerator or freezer (Figure 3). Microbes grow well in dangerous temperature area, which is between 5 and $60^{\circ} \mathrm{C}$ (Rahayu et al., 2005). If the vendors want to keep the food for more than 4 hours, such as when they have to prepare the foods early or want to save the remaining food, it is important to ensure that the foods are stored at low temperatures (below $5^{\circ} \mathrm{C}$ ) (Rahayu et al., 2005).

Inappropriate temperature control on fish-based products may increase the risk of histamine poisoning. Histamine is biogenic amine compound that is formed from an amino acid called histidine because of the activity of histidine decarboxylase enzyme, which could be sourced from the fish's body and microbes exist in its gastrointestinal tract or other contaminating microbes. Histamine poisoning symptoms start a few minutes after consuming fish, which consist of vomiting, diarrhea, swollen lips, cramps, and burning throat (Rahayu et al., 


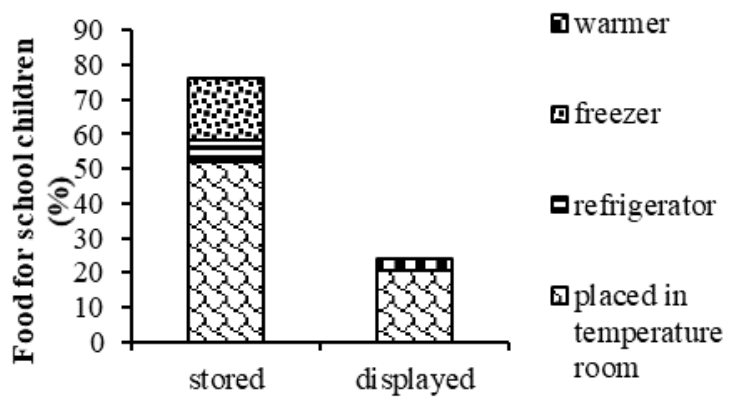

Treatment for proccessed food

Figure 3. Treatment for processed food and condition of storage

2018). It can also cause the growth of the non-indigenous bacteria such as Staphylococcus aureus, Salmonella spp., Shigella spp. and pathogenic strains of Escherichia coli that can be found in domestic or industrial waste. Those bacteria can contaminate food and cause serious illness.

One of the utilization of water by fish-based food vendors was as the heating medium in the processing stage, i.e. steaming. Although the water used was not directly mixed with the raw material, but the water must meet drinking water requirements (NADFC, 2012b). The water used by the respondents sourced from taps and wells (Figure 4). Clean water in wells did not always fulfill the standards applied in Indonesia, which are stated in the Minister of Health regulation No. 416.1990 (Minister of Health Regulation, 1990). The physical and chemical quality of water taps at 5 locations in some cities (Bogor, Jakarta, Depok, Tangerang, and Bekasi) met the criteria (91.65\%); only $8.35 \%$ were not eligible (Raini et al., 2004). Pathogenic bacteria that are commonly found in water are pathogenic strains of Escherichia coli. Escherichia coli is commonly used to monitor the microbiological quality of drinking water. The common symptoms of Escherichia coli infection are diarrhea with or without fever (Odonkor and Ampofo, 2013).

\subsection{Worker behavior}

Worker behavior includes the behavior of vendors in terms of handwashing, utensils washing, sickness handling and the use of jewelry. There were $81 \%$ of vendors who did not wash their hands before processing the food. Yet, only $59 \%$ of vendors used soap to wash their hands. Vendors who washed their hands with nonflowing water (water in the bucket) reached $44 \%$ of all the vendors. The source of water used was PDAM (state water company) water (82\%) and well water $(18 \%)$. Vendors who provided wipes to clean hands were as much as $89 \%$ of the respondents.

Keeping hands and kitchen utensils clean is very important to prevent bacterial contamination, especially

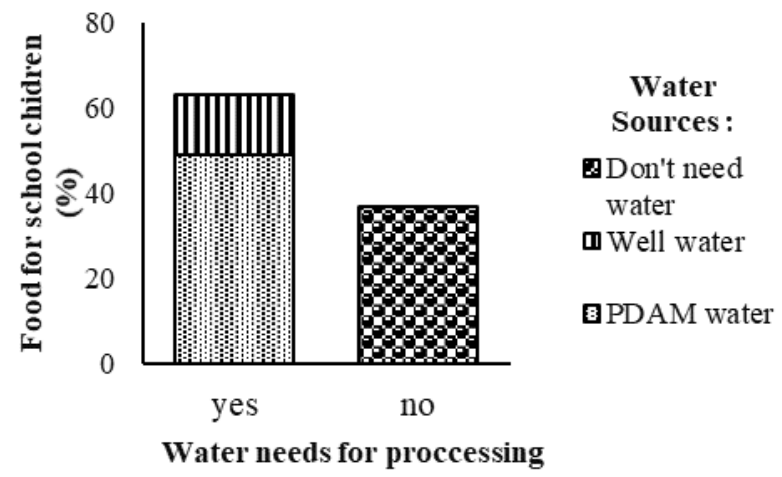

Figure 4. Interaction between water needs for processing and water sources

S. aureus. S. aureus is a normal flora on the skin and in the respiratory organs and generally found in $20-50 \%$ of the healthy population. $S$. aureus contamination in food can cause intoxication with symptoms that typically occur, i.e. nausea and vomiting, accompanied by abdominal cramps, sometimes followed by diarrhea. In severe cases, a person can suffer headache, muscle cramps and dehydration (Yunita et al., 2016)

Generally, the vendors only prepared plastic bags for waste disposal. This was due to the convenience of using plastic as a waste container because it did not require to be cleaned (Figure 5). Plastic in the open state may pose a risk because it can invite pests, which can invest hazards into food if it is placed near the food processing area. Rahayu et al. (2005) stated that pests can contaminate food and can be controlled in three ways, i.e. maintaining the cleanliness of the processing and handling place regularly, storing food in sealed containers, and closing disposal place.

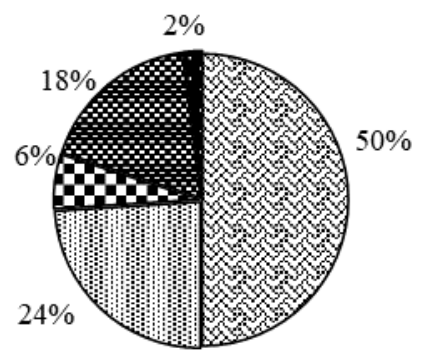

$$
\begin{aligned}
& \text { Qplastic bags } \\
& \text { Qgarbage cans (without lids) } \\
& \text { घgarbage cans (with lids) } \\
& \text { plastic bags in garbage } \\
& \text { cans (without lids) } \\
& \text { plastic bags in garbage } \\
& \text { cans (with lids) }
\end{aligned}
$$

Figure 5. Type of waste container

About $98 \%$ of the equipment used to process food for school children were washed at first. The sources of water used were tap water $(71 \%)$ and flowing water (27\%). The vendors preferred to wash their utensils using flowing water/ tap water $(60 \%)$ compared with non -flowing water $(38 \%)$. All vendors provided wipes to clean their work surfaces. Only $51 \%$ of vendors who provided cleaning materials such as soap or detergent to clean their equipment. The apron was only used by $97 \%$ of the vendors. When handling food, workers who used jewelry on their hands reached $36.5 \%$. Although physical hazards rarely cause serious injury, they are among the 
most commonly reported consumer complaints, because the injury occurs immediately or soon after eating, and the source of the hazard is often easy to identify (FAO, 2004). When vendors suffer disease, $86 \%$ of them prefer to get rest than to keep selling foods. Personal hygiene is important because according to Marriot (1985), human beings are the largest contamination sources of food. Handling with bare hands may result in crosscontamination, hence introducing microbes on food.

\subsection{Compliance to good processing practices}

The determination of the respondents' level of compliance indicated only $46 \%$ of vendors were compliant and there were still $26 \%$ of vendors who did not carry out the good food processing practices. Moreover, the observation done in this study showed that there were some main problem sources. The first one was all respondents had no access to running water to wash hands and equipment. Another source of the problem was the absence of protective clothes for the workers, which was found in $92 \%$ of the respondents. The last was the filthy conditions of the surface of the booth $(81 \%)$, the display $(65 \%)$ and also of the workers' hands $(73 \%)$.

FAO stipulates that street foods raise concern to their potential for serious food poisoning outbreaks due to improper use of additives, the presence of adulterants and environmental contaminants, and improper food handling practices amongst street food vendors (FAO, 1997). Street food vendors practiced minimal hygienic and sanitary practices. The hygienic practices in question included food preparation, handling of utensils, the place for food preparation, personal hygiene, and methods of storing cooked food (Muinde and Kuria, 2014). According to Muinde and Kuria (2014), fish vendors in Nairobi prepared their food products in the stall. Up to $92.5 \%$ of the vendors did not have garbage receptacles, hence they disposed of their garbage just near the stalls. The study in Nairobi found that proper garbage collection and disposal were lacking and vendors had to put garbage in their place (Muinde and Kuria, 2014).

According to Contento (2007), a person with a higher level of education will be better at receiving, processing, interpreting, and using information. Nasikhin et al. (2013) had found that the education level of the vendor showed a positive effect on the knowledge of prohibited substances and food hygiene and sanitation. Yet, the results obtained in this study indicated that the vendors who had junior or senior high school education were mostly compliant while most of those whose educational background was diploma/ undergraduate were only partially compliant with good processing practices (Figure 6). This result showed that the compliance level of food for school children vendors was not parallel with their educational background. Green (2008) revealed some behavioral studies, including food safety behavioral studies, which indicated that although knowledge of food safety was a component needed to change behavior, it was not enough. Egan et al. (2006) also revealed that knowledge alone was not enough to produce changes in food handling practices.

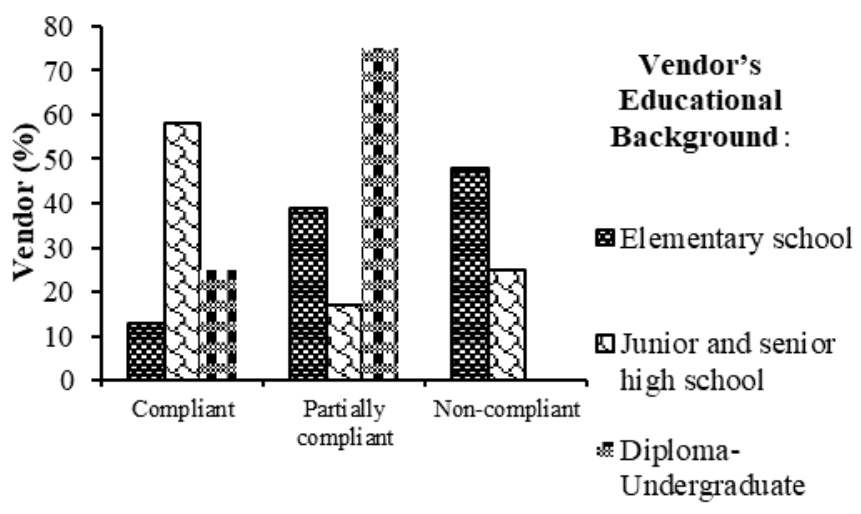

Level of Compliance

Figure 6. Interaction between the level of compliance of the vendor and the vendor's educational background

Most of the vendors who vend at the junior and senior high schools had high compliance levels while many vendors at the elementary schools had low compliance levels. Vendors who vend at the university environment were generally partially compliant (Figure 7). Kunkel et al. (2004) and Calvert (2008) stated that consumers in the children's age were unique because children were lacking the ability and cognitive skills compared with older adults. Lundberg et al. (2007) showed the opposite findings of the consumers in the children's age. They stated that children made decisions independently. The higher knowledge did not mean attitude taken would be more appropriate. On the opposite side, Mathews et al. (2005) stated that knowledge would influence the children's choice of food products.

Another factor that related to the vendors' compliance with good processing practice was the selling place (Figure 8). The location of food production and sales should be properly maintained, protected from direct sunlight and the sources of contaminants. With a permanent canteen facility and adequate water supply, generally, the vendors can implement the good processing practices. On the other side, the vendors in or outside the schoolyard with minimum facilities and water supply, and also a higher risk of contamination from air exposure, were facing difficulties in implementing the good processing practices. The lack of water for washing and cleaning the tools and personnel hygiene was the largest obstacle. The handcarts or carts also had a high potential to be polluted by contaminants. 


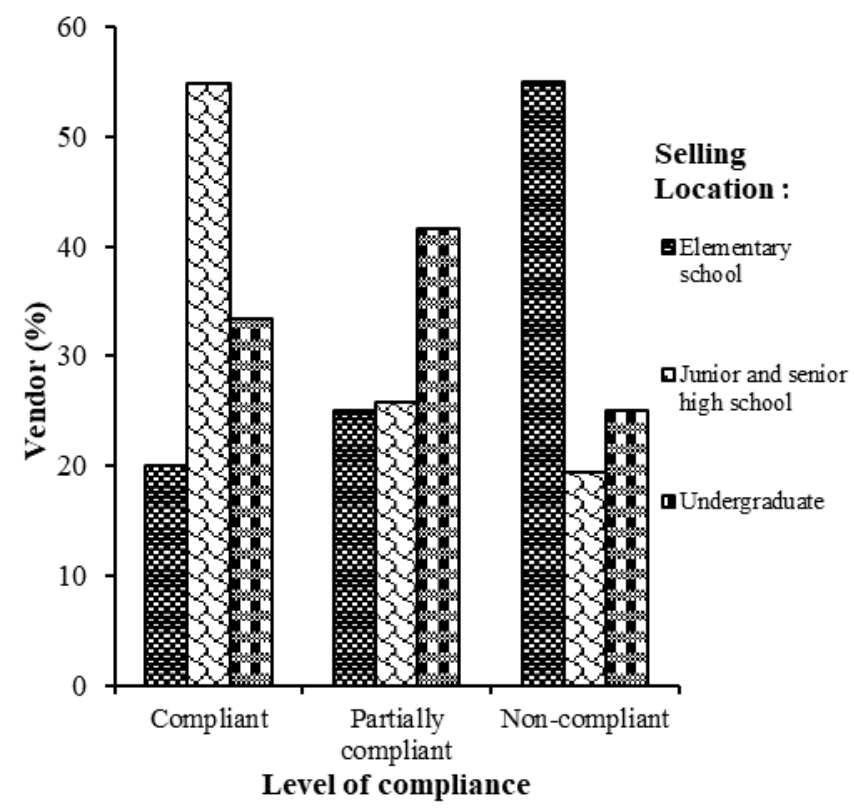

Figure 7. Interaction between the level of compliance of the vendor and selling location

Tools and facilities are the factors that allow the formation or changes in a person's behavior (Notoatmodjo, 2007). As mentioned before, supporting facilities used were adjusted to the vending place. Cart, handcart, and motor vehicle were commonly used to selling around. The moving and open conditions caused a higher risk of contamination, which was supported by minimum water supply, so it was more difficult for these vendors to comply with the good processing practices than vendors who settled. Vendors who settled generally use supporting facilities in the form of a permanent building or table (Figure 9).

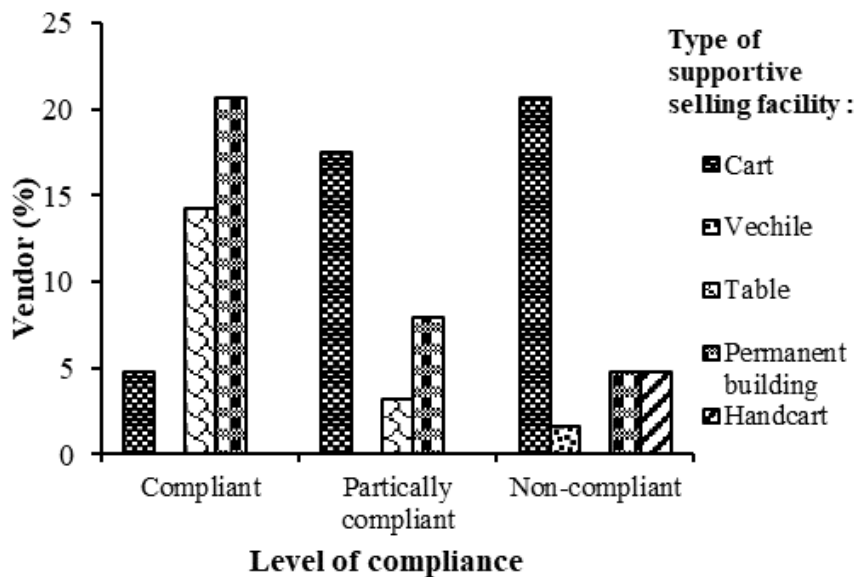

Figure 9. Interaction between the level of compliance of the vendors and supportive selling facility

The most favorite fish-based food for school children was siomay, while the food purchased most infrequently was bakso (meatballs). The level of vendors' compliance may be affected by the interest of consumers toward their products. Siomay vendors had the highest levels of compliance (Figure 10). This may happen because the vendors were aware that their products were the most favorite ones, so they vied to comply with good

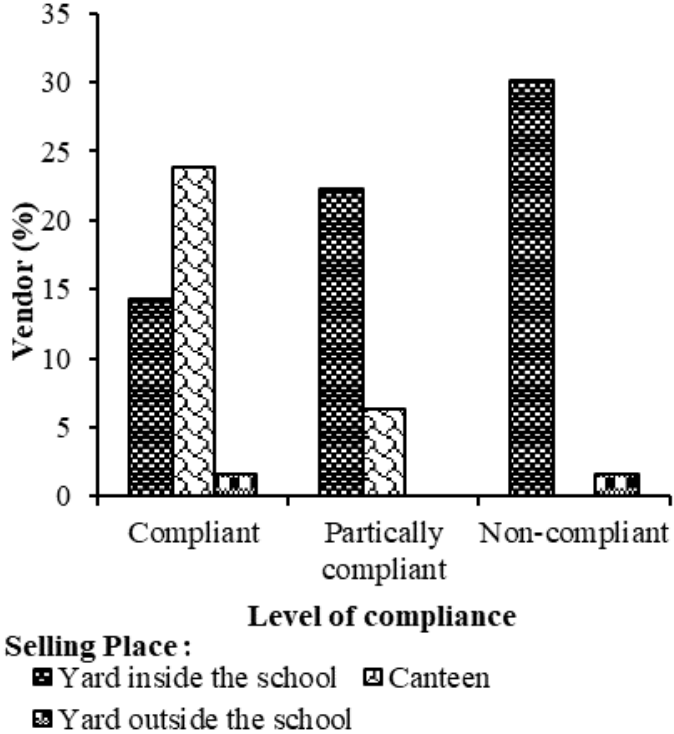

Figure 8. Interaction between the level of compliance of the vendors and selling place

processing practices so that their product would not lose its competitiveness in the market. It was different from fried meatball vendors, which were all non-compliant vendors. It can be caused by lower consumer interest compared to other kinds of food for school children. Fan and Li (2009) stated that children had a sequence of product attributes that were important in the purchase of food. These attributes were taste, price, brand, and promotion. These many different attributes on each food might lead to different levels of compliance.

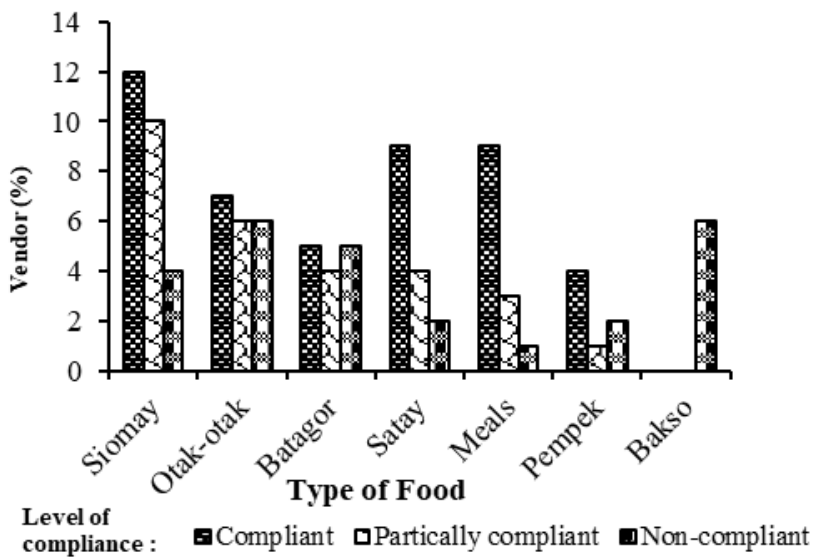

Figure 10. Interaction between the level of compliance of the vendors and type of food for school children

\section{Conclusion}

The compliance level of food for school children vendors was not parallel with their educational background. The vendors who had junior or senior high school education were more obedient to good processing practices compared to those whose educational background was diploma/undergraduate. Most of the vendors who vend at the junior and senior high schools had higher compliance levels compared to whose vend at 
the elementary school. Other factors related to the vendors' compliance were the selling place and the type of products. Consumers' awareness of buying safe food products also plays an important role that affected food vendors' compliance. The major issue for the food safety mostly were no access to running water, the absence of protective clothes, the filthy conditions of the surface of the booth, the display and the workers' hands. This can be the source of pathogen cross-contamination that cause foodborne illness to the consumers. Bacteria that cause food poisoning may be various such as $S$. aureus found in unclean hands, E. coli in water and Salmonella spp. in the environment. Based on this study, to improve vendors' compliance with good processing practices, the change of vendors' habits and mindset urgently needs to be done. It is necessary to conduct further food safety extension for the vendors to encourage them to provide proper equipment and method in processing fish-based food products.

\section{Conflict of interest}

The authors declare no conflict of interest.

\section{Acknowledgments}

The author would like to thank Higher Education Ministry of Research, Technology, And Higher Education for this research funding, with the Competence Grant scheme through Work Order No. 513/ IT3.II/LT/2015.

\section{References}

Andarwulan, N., Madanijah, S. and Zulaikhah. (2009). Monitoring and Verification of Food for School Children Safety Profile 2008. Bogor: Southeast Asian Food and Agricultural Science and Technology (SEAFAST-Center-IPB) and NADFC.

Anggitasari, A., Rahayu, W.P. and Ratnasari, Y. (2014). Effect of food safety program in elementary schools on the knowledge improvement of food vendors and students. Jurnal Mutu Pangan, 1(2), 151-158.

Calvert, S.L. (2008). Children as consumers: advertising and marketing, The Future of Children, 18(1), 205234. https://doi.org/10.1353/foc.0.0001

Contento, I.R. (2007). Nutrition Education: Linking Research, Theory, and Practice. Sudbury: Jones and Barlett Publishers.

[CSPI] Centre for Science in the Public Interest. (2001). Outbreak Alert: Closing the Gaps in our Federal Food-Safety Net. Washington DC: CSPI.

De Jong, H.K., Parry, C.M., van der Poll, T. and Wiersinga, W.J. (2012). Host-pathogen interaction in invasive salmonellosis. PLoS pathogens 8(10), e1002933. https://doi.org/10.1371/ journal.ppat.1002933

Egan, M.B., Raats, M.M., Grubb, S.M., Eves, A., Lumbers, M.L., Dean, M.S. and Adams. M.R. (2007). A review of food safety and food hygiene training studies in the commercial sector. Food Control, 18(10), 1180-1190. https://doi.org/10.1016/ j.foodcont.2006.08.001

Fan, Y. and Li, Y. (2009). A study of food buying behavior among Chinese children, In Proceedings of 38th EMAC Conference, Nantes, 2009, 26-29 May, Nantes: Brunel Business School.

FAO. (2004). Assessment and Management of Seafood Safety and Quality. Rome: FAO Fisheries

FAO. (1997). Street foods, p. 1-4. Rome: FAO.

Green, L.R. (2008). Behavioral science and food safety. Journal of Environmental Health, 71(2), 4749.

Kunkel, D., Wilcox, B.L., Cantor, J., Palmer, E., Linn, S. and Dowrick, P. (2004). Psychological issues in the increasing commercialization for childhood. Report of the APA task Force on Advertising and Children. Retrieved on April 5, 2019 from APA Website: http://www.apa.org/pubs/info/reports/advertisingchildren.aspx

Lundberg, S., Romich, J. and Tsang, K.P. (2007). Decision-Making by Children. IZA Discussion Paper (2952).

Marriot, N. (1985). Principles of Food Sanitation, p. 7080. New York: Van Nostrand Reinhold company.

Mathews, A., Cowburn, G., Rayner, M., Longfield, J. and Powell. C. (2005). The marketing of unhealthy food to children in Europe. A report of Phase 1 of the "Children, obesity and associated avoidable chronic diseases' project. Retrieved on April 8, 2019 from EHN Website: http://www.ehnheart.org/ projects/children-a-obesity/publication /54.html

Minister of Health Regulation. (1990). Permenkes No. ip 416 Year 1990 on Water Quality Requisites and Monitoring. Retrieved on April 3, 2019 from IPB Website: $\quad$ http://web.ipb.ac.id/ tml_atsp/test/ PerMenKes\%20416_90.pdf

Mabruroh, F. and Ciptaningtyas, R. (2017). Analysis of Food Poisoning in DKI Jakarta 2016 (Indonesian National Agency Drug and Food Control). In $2^{\text {nd }}$ Public Health International Conference (PHICo 2017), p. 111-118. Atlantis Press Open Access. https://doi.org/10.2991/phico-17.2018.23

Monneyl, I., Agyei, D. and Owusu. W. (2013). Hygienic practices among food vendors in educational institutions in Ghana: The case of Konongo. Foods, 
2(3), 282-294. https://doi.org/10.3390/foods2030282

Muinde, O.K. and Kuria, E. (2014). Hygienic sanitary practices of vendors of street foods in Nairobi, Kenya. African Journal of Food Agriculture and Nutritional Development, 5, 1-15.

[NADFC] National Agency of Drug and Food Control. (2012a). PerKaBPOM No. HK.03.1.23.04.12.2207 on Procedures for Inspection of Food Production Facility in Home-Industry. Retrieved on April 1, 2019 from BPOM Website: http:// standarpangan.pom.go.id/dokumen/peraturan/2012/ Perka_BPOM_No_HK.03.1.23.04.12.2207_Tahun_2 012_tentang_CPPB_PIRT.pdf

[NADFC] National Agency of Drug and Food Control. (2012b). PerKaBPOM No. HK.03.1.23.04.12.2206 on Good Food Processing Practices for Homeindustry. Retrieved on April 1, 2019 from BPOM Website: http://standarpangan.pom.go.id/dokumen/ peraturan/2012/

Perka BPOM No HK.03.1.23.04.12.2206 Tahun 2 012_tentang_CPPB_PIRT.pdf

[NADFC] National Agency of Drug and Food Control. (2013). A Movement to Safe, Good, and Nutritious Food for School Children. Jakarta: NADFC.

Nasikhin, U., Wariyah, C. and Dewi, S.H.C. (2013). Hubungan Tingkat Pendidikan Pedagang dengan Hygiene Sanitasi Makanan Jajan Anak Sekolah Dasar di Kabupaten Kulon Progo-DIY. Jurnal AgriSains, 4, 23-37. [In Bahasa Indonesia].

Notoatmodjo, S. (2007). Public Health: Science and Art. Jakarta: Rineka Cipta.

Odonkor, S.T. and Ampofo, J.K. (2013). Escherichia coli as an indicator of bacteriological quality of water: an overview. Microbiology Research, 4(1), e2. https://doi.org/10.4081/mr.2013.e2

Rahayu W.P., Nababan, H., Syah, D., Nuraida, L., Syamsir, E., Susigandhawati, E. and Puspitasari, R. (2005). Food Safety Counseling. Jakarta: SPKP Directorate, Deputy III NADFC Indonesia.

Rahayu, W.P., Utari, I.W., Nurwitri, C.C. and Nurjanah, S. (2018). Determination of critical control points in fish-based snacks preparation as foods for school children. International Food Research Journal, 25 (6), 2285-2291.

Raini, M., Isnawati, A. and Kurniati. (2004). Physical and chemical quality of tap water in Jakarta, Bogor, Tangerang, Tangerang, Bekasi year 19992001. Media Litbang Kesehatan. 14(3), 14-19.

Sarwono, J. (2006). Research Data Analysis Using SPSS. Yogyakarta: Andi.

Setiawan, N. (2005). Sampling Technique. Social Research Methodology Training. Indonesia:
Padjajaran University.

[WHO] World Health Organization. (2015). WHO estimates of the global burden of foodborne diseases: foodborne disease burden epidemiology reference group 2007-2015. World Health Organization. Switzerland: WHO.

Yunita, N.A., Rahayu, W.P., Suliantari, Nurjanah, S. and Nurwitri, C.C. (2016). Identification and probability of illness of S. aureus contaminated food for school children. International Food Research Journal, 23 (4), 1767-1772. 